\title{
The Effect of Integration of Islamic Values in Quantum Learning on Student Learning Outcomes and Attitudes
}

\author{
Muflihah \\ Chemical Education Program \\ Teacher Training and Education \\ Faculty of Mulawarman University \\ Samarinda, Indonesia \\ muflihah@fkip.ac.id
}

\author{
Eka Normawati \\ Chemical Education Program \\ Teacher Training and Education \\ Faculty of Mulawarman University \\ Samarinda, Indonesia \\ ekanormawat@gmail.com
}

\author{
Iis Intan Widiyoawati \\ Chemical Education Program \\ Teacher Training and Education \\ Faculty of Mulawarman University \\ Samarinda, Indonesia \\ iis.intan@fkip.unmul.ac.id
}

\begin{abstract}
This study aimed to determine the effect of integration of Islamic values in quantum learning model on student learning outcomes on the subject of reduction and oxidation reactions. This research was conducted at senior high school namely Sekolah Menengah Atas (SMA) Nabil Husein Samarinda, East Kalimantan province, Indonesia. Subject of this research were two groups of tenth-grade students of natural science that have been chosen by purposive sampling. A group student namely students X IPA 1 was used as experimental group and a group student namely students $X$ IPA 2 was used as control group. Each group consisted of 21 students. This research is categorized as a quasi-experimental; non-equivalent control group design. Data in this research were student learning outcomes before research, teacher and student activities, and student learning outcome after research, and in order they were collected by using documentation, observation and test techniques. Some statistical analyzed were used; $F$ and $t$ tests. Result of this research shows that average student learning outcomes of experimental group was 82.13 and control group was 77.67, and significantly different. It is indicate that the integration of Islamic values in quantum learning model positively influence the student learning outcome on the subject of reduction and oxidation reactions, tenth grade students of natural science, SMA Nabil Husein Samarinda.
\end{abstract}

Keywords: integration level philosophy, strategy, material, methodology

\section{INTRODUCTION}

Kurikulum 2013, also known as K-13, is a curriculum that applies in Indonesian education system. K-13 is a curriculum based on character and competence, and has been applied at all levels of the education unit in Indonesia, including senior high school. Based on the curriculum, students must reach a minimum score namely kriteria ketuntasan minimum (KKM), and good character. However, to reach the KKM, some students cheated such as copying on friends' answers and/or opening books/cheat sheets during tests. Those are producing bad characters.

The student characters can be formed by integrating Islamic values in learning. Good cognitive knowledge and good characters based on Islamic values of students can be created by conducting integrated learning [1]. Integration of Islamic values in science subjects does not reduce student knowledge. It will increase students' faith and piety to God [2] and as the result, students' good character is formed [3]. Al-Quran, Surah An-Nahl (68-69) asserts that the reactions that occur in the universe are basis of development of science, especially chemistry.

In chemistry, students learn many reactions including reduction and oxidation reactions. Studying those reactions can increase student faith and piety. Besides, there are also holy verses of the Qur'an that describe these events. The oxidation reduction reactions topic is conveyed to tenthgrade students of natural science. They have to understand the topic as a basic to understand advanced topics in higher grade. Based on authors' observation, students are unable to understand the reduction and oxidation reactions topic. Mostly, it is due to lack of students' interest. Student interest can be affected by many factors including learning methods and models. Therefore, chemistry teachers are expected to be able to present interesting and innovative materials [5].

The learning model that emphasizes meaningful learning and student enjoyment is a quantum learning model [4]. The model is effective in improving student learning outcomes on the stoichiometry subject. There are six steps in quantum learning model i.e. grow, natural, name, demonstrate, repeat, and celebrate. Based on the steps, the model can be used as a strategy to integrate Islamic values in learning reduction and oxidation reactions. Students are able to receive the knowledge with a pleasant atmosphere, pay attention and active in the learning process, and easy to remember and understand the concept and theory, so they can apply their knowledge in their daily [4].

A research was reported that integrated Islamic values in learning process using inquiry model significantly improve student understanding on the concept of buffer solution [5]. Another research reveals fact that integrated spiritual values in learning sources of chemistry using collaborative-oriented problem based learning (PBL) models could increase students understanding about chemical bonding.

Based on the mentioned background above, authors were interested to conduct a research about the influence of the integration of Islamic values in learning using quantum model on the learning outcomes of tenth-grade high school students on the subject of reduction and oxidation reactions.

\section{METHOD}

This research was conducted at SMA Nabi Husein Samarinda, East Kalimantan, Indonesia. Subjects of this research were tenth-grade students of natural science and were selected by purposive sampling. A group student, 
consist of 21 students, namely students X IPA 1 as an experimental group and a group of student, consist of 21 students, namely students X IPA 2 as a control group. This research is a quasi-experimental research using nonequivalent control group design.

At the beginning and the end of learning, students were given an attitude questionnaire, which was used to determine the influence of the integration of Islamic values on student attitudes. Student learning outcomes are obtained from posttest and subject final tests. There were 3 meetings in this research; two meetings were learning process and remaining meeting was final subject test. Post-tests were given at the end of the learning; three questions were given at the $1^{\text {st }}$ meeting, four questions at the $2^{\text {nd }}$ meeting. Twenty one questions were given as final subject test, 15 multiple choice questions and 6 essay questions. The questions were made based on the learning indicators.

There were some data used in this research. First data was student learning outcomes that took before the research, and it was collected by using documentation technique. This data was used for F-test in order to measure the homogeneity of the samples. Second data was student attitudes that collected by using questionnaire. It was measured before (pre-test) and after (post-test) research. The improved student attitudes were calculates as $\mathrm{N}$ Gain following equation (1). The data is processed by using [7]. Third data was student learning outcomes on the subject of reduction and oxidation reactions that took by using test. The test was post tests and final subject test. The student learning outcomes was obtained by equation (2) [11]. Other supporting data were student and teacher activities that observed during the learning process.

$$
\mathrm{N} \text { Gain }=\frac{\text { post-test score }- \text { pre-test score }}{\text { maximum score }- \text { pre-test score }}
$$

$$
\mathrm{SLO}=\left(30 \% \mathrm{PTS}_{1}+30 \% \mathrm{PTS}_{2}+40 \% \mathrm{SFST}\right)
$$

where SLO is student learning outcomes, $\mathrm{PTS}_{1}$ and $\mathrm{PTS}_{2}$ are student post-test score at the $1^{\text {st }}$ and $2^{\text {nd }}$ meetings, and SFST is student score at final subject test.

\section{RESULTS AND DISCUSSION}

Samples used in this research was homogeny (data is not shown). Student learning outcomes of experimental and control group are shown in Fig. 1. According to Fig. 1, it is clear that student learning outcome of experimental group is significantly higher than that of control group.

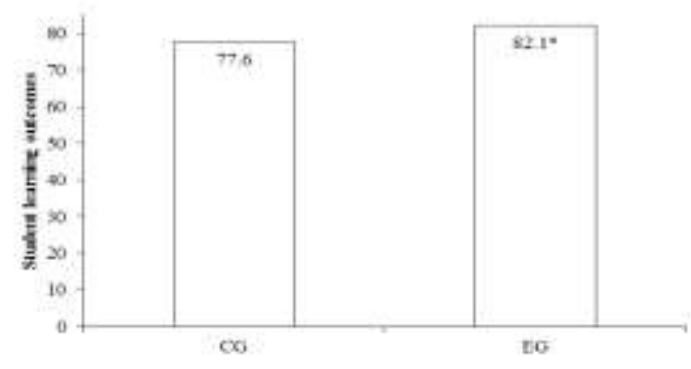

Fig. 1. Student learning outcomes, CG is control group and EG is experimental group, *significantly different with the lefth value.
An integration Islamic value in quantum learning model on the subject of reduction and oxidation reactions at the experimental group made student more active. In the learning, students were required to link Islamic values from Al-Qur'an and Hadist to studied topic. Motivations were always connected to Hadist and the explained topic and supported by Al-Qura'an. Students were active in learning, asked a lot of questions, and were happy to answer teacher questions. In addition, they always wrote the important explanation from teacher. As the result, they were easy to understand concepts in the reduction and oxidation reactions subject. Thus their learning outcomes were high and satisfying.

In the class, students showed a good team work. They showed a high level gratitude, and admired God's creation. Learning began with reading basmallah and end by reading alhamdulillah. This fact showed student piety. In addition, students were confidence and not easily discourage. $\mathrm{N}$ gain (data is not shown) score showed that the students attitude increased. So the integration of Islamic value in quantum learning model on the subject of reduction and oxidation reactions at experimental group could increase student attitudes.

This result is in accordance with previous researches. As in [9]-integration of Islamic values into learning instills trust, faith and piety of students to Allah subhanahuwata'ala. The integration of Islamic values in learning system enhances students' scientific experiences, thereby providing opportunities for them to improve their achievements [10]. Learning model integrated with facts in Al-Qur'an significantly improve students' understanding during learning process [5]. Integrated Islamic value was effectively implemented in learning of thermochemistry subject [2].

\section{CONCLUSION}

Integration of Islamic values in quantum learning model influence the students learning outcomes and attitudes of research subjects; tenth grade students of natural science at SMA Nabil Husein Samarinda, on the subject of reduction and oxidation reactions.

\section{ACKNOWLEDGMENT}

Authors thank to headmaster and chemistry teachers of SMA Nabil Husein Samarinda who have been facilitated authors to conduct this research.

\section{REFERENCES}

[1] Nihayati, "Integration of Islamic values with the assemblage subject (study of the verses of Al-Quran)," Edumath Journal, vol. 3(1), 2017, pp. 65-77.

[2] A. Darmana, "Internalization of the value of tauhid in science learning," Journal of Islamic Education, vol. 17, 2012, pp. 66-84.

[3] M. Nurhadi, A. Rasyidin, and A. Imran, "The integration of Islamic values in biology learning at the Al Ulum Integrated Islamic High School in Medan,” Edu Riligia Journal, vol. 1, 2017, pp. 487-501.

[4] W. Astutik, "A quantum learning model to improve learning outcomes on fraction subject" Journal of Research and Conceptual, vol. 2, 2017, pp. 124-129.

[5] Safrijal, A. Halim, and Mustanir, "The inquiry learning model integrated the verses of Al-Qur'an to improve understanding of the concept of buffer solutions and the Islamic character of student," Journal of Indonesian Science Education, vol. 3, 2015, pp. 195-206. 
[6] H. Okmarisa, A. Darmana, and D.R. Suyanti, "Implementation of chemistry teaching materials integrated spiritual values with collaborative-oriented problem-based learning models to improve student learning outcomes" Journal of Chemical Education, vol. 8, 2016, pp. 130-135.

[7] R. Sudayana, Educational research statistics, Bandung: Alfabeta, 2014.

[8] A.E Setyanto, "Reintroducing the experimental method in communication studies," Journal of Communication Sciences, vol. 3 , 2015, pp. 37-48.
[9] N. Muspiroh, "Integration of Islamic values in science learning in schools," Journal of Islamic Education, vol. 2, 2013, pp. 172-182.

[10] U. Fakhruddin, E. Bahruddin, and Mujahidin, "The concept of integration in the learning system of general subjects in Islamic boarding schools," Journal of Islamic Education Ta'dibuna, vol. 7, 2018, pp. 214-232.

[11] Pramudjono, Non parametic statistic, Samarinda: Faculty of Teachers Training and Education of Mulawarman University, 2010. 